\title{
SIZE AT FIRST MATURITY OF THE BLUE SPOTTED MASKRAY, Neotrygon kuhli IN INDONESIAN WATERS
}

\author{
Fahmi ${ }^{1)}$, Mohammad Adrim ${ }^{1)}$, and Dharmadi ${ }^{2)}$ \\ 1) Research Centre for Oceanography-Indonesian institute of Sciences, Ancol-Jakarta \\ 2) Research Centre for Capture Fisheries, Ancol-Jakarta \\ Received January 8-2009; Received in revised form January 21-2009; Accepted February 9-2009
}

\begin{abstract}
The blue spotted maskray, Neotrygon kuhlii is the most common rays occurred in Indonesian waters. This species is often caught as bycatch in trawl fisheries targeting demersal fishes and shrimps. The unselected and intensive catches of this species can influence to its sustainable in the future. A study on this species was conducted at several areas in Indonesia from 2003 to 2006 . A total of 1,122 individuals, consisting of 523 females and 599 males were measured from some areas in western Indonesia including the Java Sea, the Malacca Strait, South Java, East Sumatera, West Kalimantan, and South Natuna waters. Size ranges of Neotrygon kuhlii were varied among regions. in general, mature individuals were caught more often than neonates in all areas. The minimum size was $130 \mathrm{~mm}$ disc width and maximum size was $415 \mathrm{~mm}$ disc width. Females usually produce one pup in its reproduction cycle and the smallest recorded pregnant female was $240 \mathrm{~mm}$ disc width while the largest was $317 \mathrm{~mm}$ disc width. Males attain maturity at size between 215 and $295 \mathrm{~mm}$ disc width. There were also differences in size at first maturity for Neotrygon kuhlii caught from each area. The rays seemed to be mature earlier at the Java Sea, West Kalimantan, East Sumatera and the Malacca Strait, as an indication of the plasticity in their life histories to cope with fishing pressure and environmental degradations in their habitats.
\end{abstract}

KEYWORDS: $\quad$ maturity, Neotrygon kuhlii, indonesia

\section{INTRODUCTION}

The blue maskray whipray, Neotrygon kuhlii, is one of the most common rays occurred in Indonesian waters. This species, which is formerly known as Dasyatis kuhlii (see Last \& White, 2008), is a smallsize ray and known distributed throughout the IndoWest Pacific from India to Melanesia, including southern Japan and Australia (Last \& Compagno, 1999; White et al., 2006b). As demersal fishes, Neotrygon kuhlii can be found on insular and continental shelves to a depth of $90 \mathrm{~m}$. This species is commonly caught as by catch by various fishing gears such as bottom trawls, bottom lampara nets, danish seine nets and trammel nets. This species, together with Dasyatis zugei, Himantura gerrardi, and Himantura walga, contributed about $75 \%$ of the total batoids caught by fisheries in eastern Indonesia during a study from 2001 and 2006 (White \& Dharmadi, 2007). While in a study in western Indonesia from 2003 to 2005, Neotrygon kuhlii also contributed about $55 \%$ of the total abundance of recorded chondrichthyans during the study (Adrim \& Fahmi, 2007).

Elasmobranch fisheries in Indonesia has become international concern due to its status as the highest total catch of cartilaginous fishes in the world (Bonfil, 1994; Stevens et al., 2000). Some authors suggested that elasmobranchs are fully exploited in Indonesian waters with indications of depletion in some areas, especially in the Java Sea and adjacent waters (Bonfil, 2002; White et al., 2006b). Some common species become the targets of fishing due to the high value of their fins or skins (i.e. rhynchobatids and some dasyatids). However, management and corıservation actions are difficult to implement for such species when basic data on biology and diversity of elasmobranch are either very few or not available in the region. Therefore, some high valued species are already threatened before any management responses could be put into place (Camhi et al., 1998).

Studies on elasmobranch biology and life histories conducted in the Pacific region over the last few decades have included age and growth, reproduction, diet analysis to provide knowledge for sustainable fishing and management (Seki et al., 1998; Oshitani et al., 2003; Joung et al., 2004). Study on reproductive cycle, gestation period, size at maturity, and number of pups are basic knowledge for understanding species life history (Simpfendorfer, 1992; Liu et al., 1999). Knowing size at first maturity is essentiai that allows us to examine mature and spawning stocks for managing the species exploitation (Jennings et al., 1998). Furthermore, Frisk et al. (2001) suggested that further knowledge on age, fecundity, mortality, and growth is crucial to realize conservation for elasmobranchs. This study is a complement of previous studies on biology of Neotrygon kuhlii in Indonesia (White \& Dharmadi, 2007) and provides 
detailed information on maturity stage of the species from several areas in western Indonesia

\section{MATERIALS AND METHODS}

\section{Data Collection and Measurements}

Data were collected from many fish landing sites in Sumatera, Java, and Kalimantan from June 2003 to October 2006 . Fishing areas were based on where fishers landed their catches at particular landing sites, e.g. the west north Java region was taken from data collected at Muara Angke and Muara Baru landing sites; east north Java region was from Pekalongan, Batang, Rembang, and Brondong landing sites; south Java region was taken from Binuangeun and Pelabuhan Ratu; the Malacca region was from Belawan and Tanjung Balai; east Sumatera region was from Bangka and Lampung; west Kalimantan region was from Mempawah and Sungai Pinyuh landing sites; and South Natuna region was taken from data collected at Sungai Kakap landing site. Analysis of variance was used to compare the significance of differences mean disc width of Neotrygon kuhlii among region, and post hoc tests was performed using Fisher's least significant difference test to compare the mean values among region to find out where exactly the significant differences are (Howell, 1997; Zar, 1999). The maturity stages of males are based on the calcification condition of their claspers and divided into three categories i.e. claspers not calcified, not fully calcified, and fully calcified (Dharmadi \& Fahmi, 2006; White et al., 2006a; White \&. Dharmadi, 2007). Immature males are indicated by the small, flexible and uncalcified claspers. Claspers swiftly lengthen and harden when males reach maturity. Males were considered fully mature if their claspers are elongate, rigid, and calcified (Stevens \& McLoughlin, 1991). The maturity stages of females were determined by the presence of embryos, large developing ova, and enlargement of their uteri (Wetherbee et al., 1997; Hazin et al., 2001; White et al., 2002). The examination of female reproduction was conducted only when the species was being processed in the market and embryos were counted if existing. Size at first maturity of males was assessed by plotting clasper length against body size (total length or disc width), according to the calcification of the claspers. Whilst the $50 \%$ of males attain maturity (the $\mathrm{DW}_{50}$ at maturity) was derived from a logistic regression (White et al., 2006a), where the proportion $\left(P_{D W}\right)$ of those rays that were mature at size disc width was calculated as follows:

$$
p_{D W}=\frac{1}{1+\exp \left[-\ln (19) \frac{\left(D W-D W_{50}\right)}{\left(D W_{95}-D W_{50}\right)}\right] \ldots \text { (1 }}
$$

where:

$$
\mathrm{DW}_{50} \text { and } \mathrm{DW}_{95} \text { are constants }
$$$$
\mathrm{Ln} \quad=\text { the natural logarithm }
$$

Maximum likelihood estimates of the parameters were acquired using the SOLVER in MS Excel program and calculating the likelihood of immature $\left(1-P_{D W}\right)$ and mature individuals $\left(P_{D W}\right)$. The estimates of the parameters were determined as the median values resulting from 200 sets of randomly resampled data, drawn from the size data on the observed maturity stage for males. The $95 \%$ confidence intervals were estimated as the 2.5 and 97.5 percentiles from the results of the 200 estimates.

\section{RESULTS AND DISCUSSION}

A total of 1,122 individuals of Neotrygon kuhlii, consisting of 523 females and 599 males were measured was recorded from twelve landing sites in west central Indonesia. In general, size ranges of Neotrygon kuhlii from the study areas were from 130 to $465 \mathrm{~mm}$ DW for females and from 130 to $415 \mathrm{~mm}$ Disc width for males, with a large number of individuals recorded in the 240 to $259 \mathrm{~mm}$ disc width size class (Figure 1). Whilst size ranges of each fishing region and the mean values of their disc widths are showed in Table 1. The analysis of variance test showed a significant difference among the mean disc width of Neotrygon kuhlii from each region $(P<0.05)$. The mean disc width of Neotrygon kuhlii from east Kalimantan was the largest and mean disc width of the species from West Kalimantan was the smallest (Table 1).

The mean disc width values of Neotrygon (Dasyatis). Neotrygon kuhlii from west and east north Java regions were a slight larger than those recorded by Mardlijah \& Pralampita (2004) from the Java Sea in 2002. While the size range of Neotrygon kuhlii (Java form) recorded from a study in eastern Indonesia in 2002 and 2003 (White \& Dharmadi, 2007) was about similar to those recorded from the west and east north Java, south Java, Malacca, and east Sumatera regions, whiles size range of Neotrygon kuhlii (Bali form) was about similar to those recorded in south Natuna. 


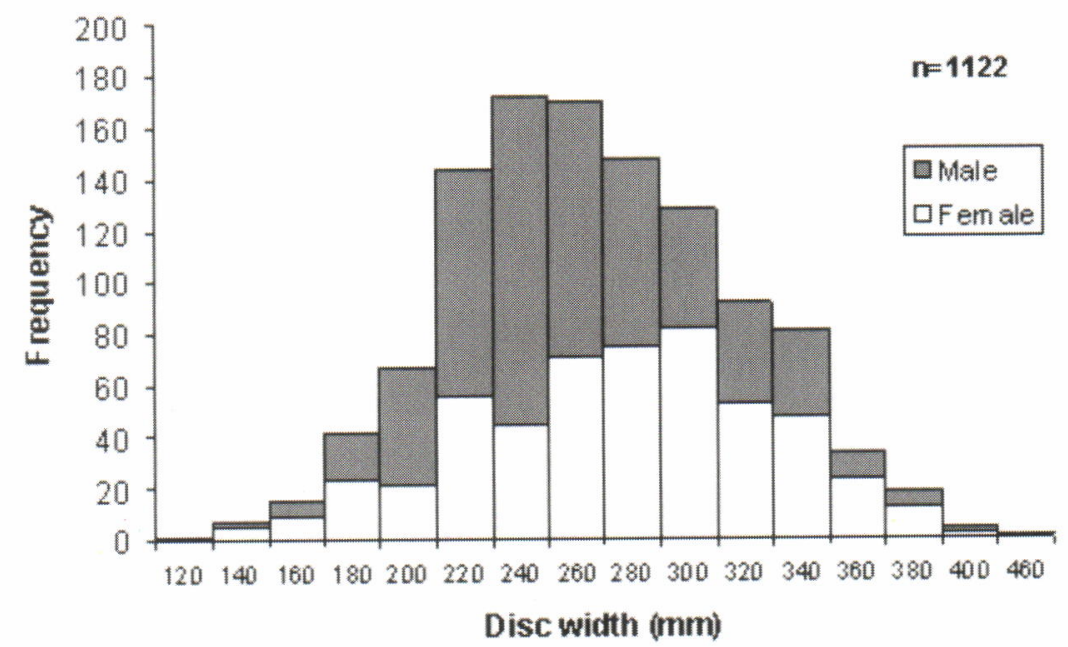

Figure 1. Stacked bar graphs of disc width frequency of Neotrygon kuhlii from six fishing areas in western Indonesia.

Table 1. Size ranges of Neotrygon kuhlii caught from each fishing area in western Indonesia

\begin{tabular}{lccccc}
\hline \multirow{2}{*}{ Fishing area } & \multirow{2}{*}{ Female $(\mathbf{m m})$} & Male $(\mathrm{mm})$ & \multicolumn{3}{c}{ Mean $(\mathrm{mm})$} \\
\cline { 4 - 6 } & & & Female & Male & Female + Male \\
\hline West North Java & $165-363$ & $145-372$ & 266.2 & 245.3 & 253.3 \\
East North Java & $130-370$ & $130-330$ & 278.5 & 251.2 & 265.7 \\
South Java & $150-395$ & $200-360$ & 288.9 & 293.2 & 290.9 \\
Malacca & $130-355$ & $185-339$ & 277.2 & 264.5 & 272.1 \\
East Sumatera & $160-400$ & $160-350$ & 273.8 & 254.1 & 263.8 \\
West Kalimantan & $250-295$ & $160-275$ & 248.7 & 239.5 & 242.2 \\
East Kalimantan & $265-395$ & $265-390$ & 332.0 & 324.0 & 326.6 \\
South Natuna & $228-465$ & $140-380$ & 328.2 & 316.2 & 320.3 \\
\hline
\end{tabular}

The smallest pregnant female recorded was 210 $\mathrm{mm}$ disc width with one embryo inside the uterus (male, $100 \mathrm{~mm}$ disc width) and the largest pregnant female was 385 disc width (female, $145 \mathrm{~mm}$ disc width), both sizes were recorded from Batang landing site (east north Java region). Due to the small number of pregnant females being recorded, estimation for female maturity could not be determined based on the fishing region, but in general females attain their maturity in western Indonesia at size between 210 and $240 \mathrm{~mm}$ disc width. This size range was larger than those recorded by Mardlijah \& Pralampita (2004) in the Java Sea in 2002. The number of pups varied between one and two, but usually pregnant females only have a single embryo. The largest embryo recorded was a female embryo (160 $\mathrm{mm}$ disc width) from a $320 \mathrm{~mm}$ disc width mother, while the smallest young was $130 \mathrm{~mm}$ disc width. Therefore, the size at birth was possibly between 130 and $160 \mathrm{~mm}$ disc width. This size range is about similar to Neotrygon kuhlii (Java form) recorded by White \& Dharmadi (2007). The range of size at birth of Neotrygon kuhlii (Java form) in White et al. (White et al., 2006b) was a bit wider, which was from 110 to $160 \mathrm{~mm}$ disc width.
Size at first maturity of males varied among regions. The smallest mature males from west north Java region, east north Java, south Java, East Kalimantan, West Kalimantan, the Malacca Strait, east Sumatera, and South Natuna region were 215, $215,275,295,220,250,240$, and $280 \mathrm{~mm}$ disc width, respectively. In contrast, the largest immature males from those regions were $250,270,280,310,245,250$, 255 , and $320 \mathrm{~mm}$ disc width, respectively (Figure 2). Therefore, it can be concluded that males Neotrygon kuhlii attain their first maturity in Indonesia at size between 215 and $295 \mathrm{~mm}$ disc width, depending on the region. The $\mathrm{DW}_{50}$ at maturity with $95 \%$ confidence intervals of males Neotrygon kuhlii from each region are presented in Table 2.

Table 2, shows that $50 \%$ of males Neotrygon kuhlii population from East Sumatera region attained maturity at smaller size than those species from other regions, following by west north Java and west Kalimantan, respectively. On the other hand, males from South Natuna and East Kalimantan regions attained maturity at larger size. Males Neotrygon kuhlii are known attained maturity at size about $250 \mathrm{~mm}$ 

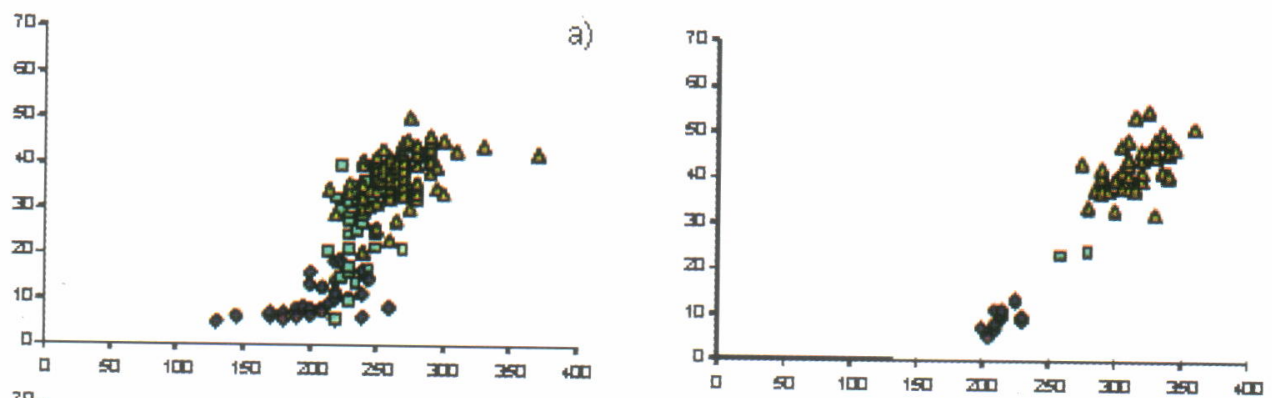

b)
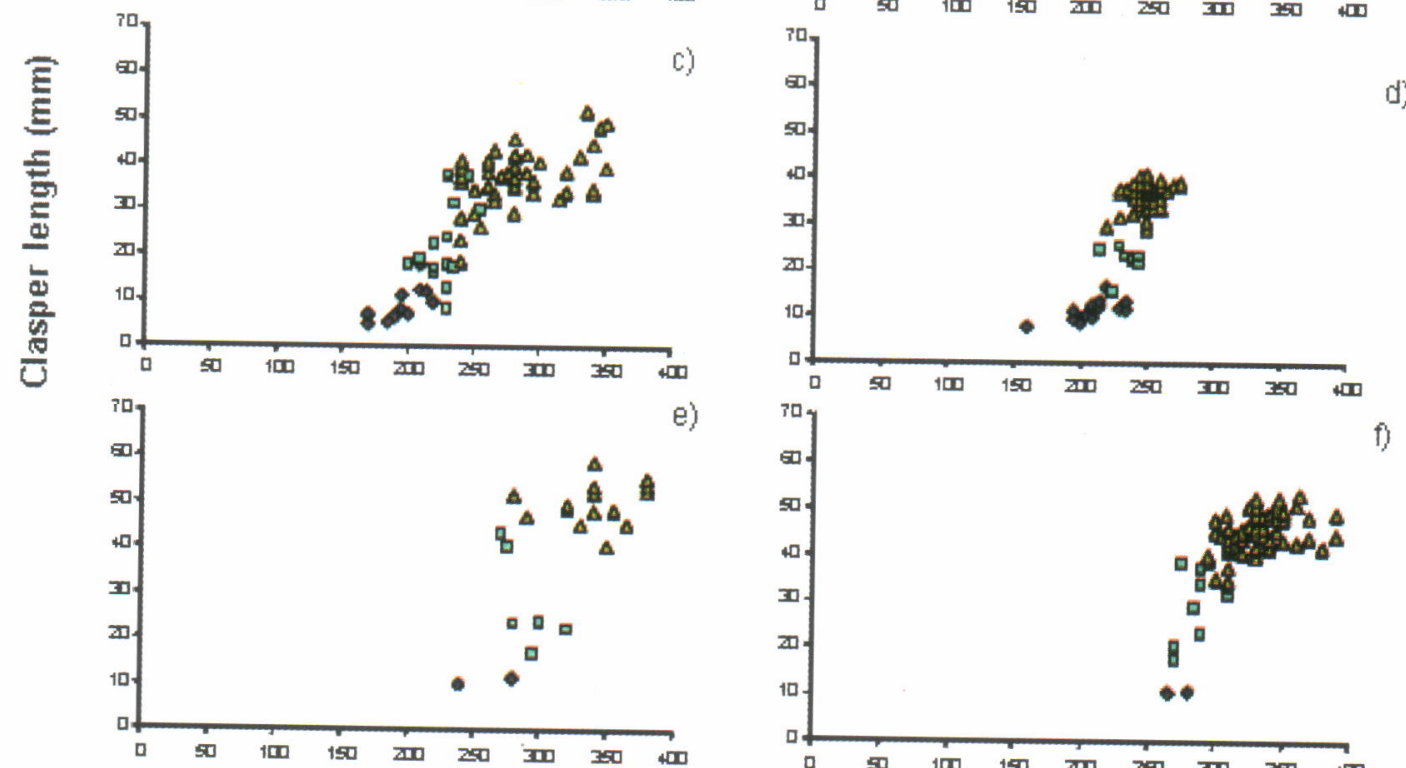

e)
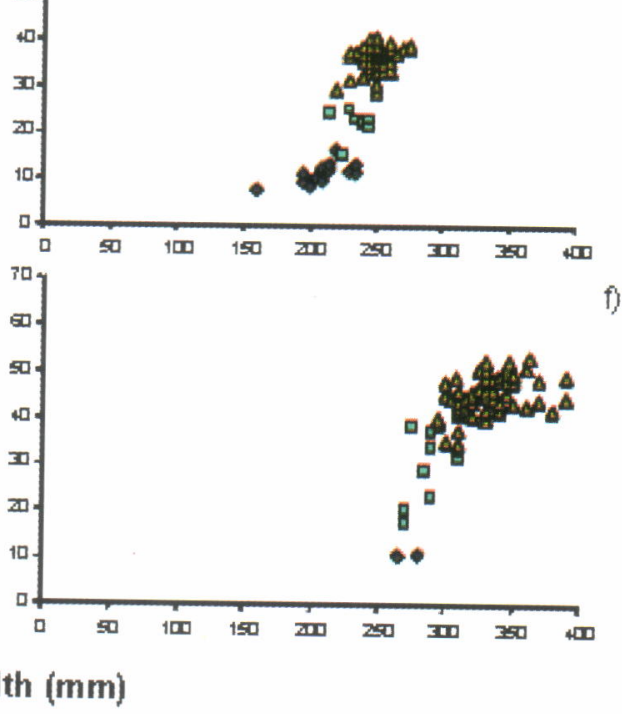

NC= not calcified $\square \mathrm{MFC}=$ not fully calcified $\triangle \mathrm{FC}$ fully calcified

Figure 2. Size at maturity of males Neotrygon kuhliifrom a) North Java; b) South Java; c) East Sumatera; d) West Kalimantan; e) South Natuna; and f) Wast Kalimantan.

Table 2. The size at $50 \%$ of males Neotrygon kuhlii $\left(\mathrm{DW}_{50}\right.$ ) attained maturity (with $95 \%$ confidence intervals) from each fishing region in Indonesia

\begin{tabular}{lcccc}
\hline \multirow{1}{*}{ Fishing region } & DW $_{\mathbf{5 0}}(\mathbf{m m})$ & \multicolumn{2}{c}{ 95\% confidence interval } & \multirow{2}{*}{ N } \\
\cline { 3 - 4 } & 246.3 & 205.2 & 279.1 & 166 \\
West North Java & 252.2 & 204.9 & 296.7 & 120 \\
East North Java & 256.6 & 220.8 & 296.9 & 60 \\
South Java & 249.8 & 201.9 & 298.2 & 20 \\
Malacca & 235.5 & 202.4 & 258.9 & 74 \\
East Sumatera & 245.3 & 202.4 & 277.1 & 65 \\
West Kalimantan & 288.3 & 251.6 & 317.9 & 71 \\
East Kalimantan & 304.8 & 251.8 & 347.1 & 23 \\
South Natuna & & & & \\
\hline
\end{tabular}

disc width (Last \& Compagno, 1999) but in White et al. (2006b), males Neotrygon kuhlii (Java form) attain maturity at size between 220 and $230 \mathrm{~mm}$ disc width, while Neotrygon kuhlii (Bali form) is at size between 310 and $320 \mathrm{~mm}$ disc width.

According to Last \& Compagno (1999), differences in color morphs of Neotrygon kuhlii in the Indo Pacific region could lead to the possibility of more than one species of Neotrygon kuhlii occur in the region. On the other hand, White et al. (2006b) identified at least two forms of Neotrygon kuhlii in eastern Indonesia, which differ both maximum sizes and sizes at maturity, i.e. the Java form (attains at least $380 \mathrm{~mm}$ disc width) and the Bali form (attains at least $450 \mathrm{~mm}$ disc width). The size differences of size at maturity of 
Neotrygon kuhlii may lead to the assumption that Neotrygon kuhlii from west and east North Java, South Java, Malacca, East Sumatera, and West Kalimantan regions were morphologically the same species or within the same population structure with Neotrygon kuhlii (Java form), due to the similarity in size at maturity, body shape and also the color morphs (Figure 3a). In contrast, Neotrygon kuhlii from South Natuna and East Kalimantan could be in separate group due to the differences in the body size. Neotrygon kuhlii from those regions (South Natuna and East Kalimantan), which were differ from Neotrygon kuhlii (Java form) in the size at maturity, may be similar to
Neotrygon kuhlii (Bali form). However, the color morphs and disc shape between Neotrygon kuhlii (South Natuna and East Kalimantan) and the the Bali form species were visually different. The blue spots on the dorsal surface of Neotrygon kuhliifrom South Natuna and East Kalimantan were darker than Neotrygon kuhlii (Bali form) and their disc shapes were less similar (Figure $3 b, c)$. Therefore, there is a possibility that Neotrygon kuhlii from South Natuna and East Kalimantan may be in separate group from both the Java and Bali forms. Nevertheless, genetic analysis may be a better tool to determine the differences between those groups.

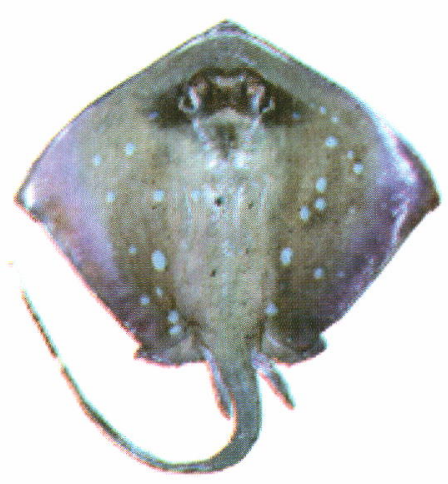

a. Java form.

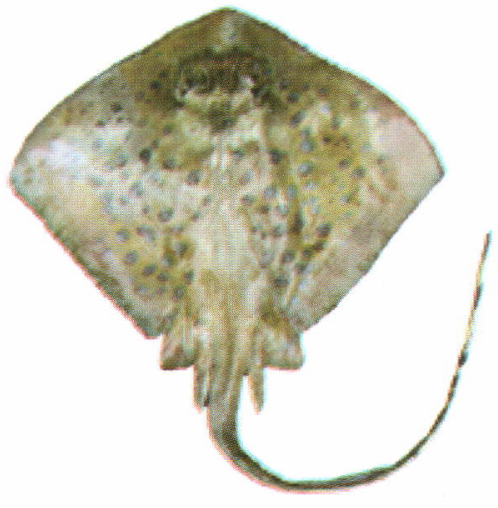

b. South Natuna form.

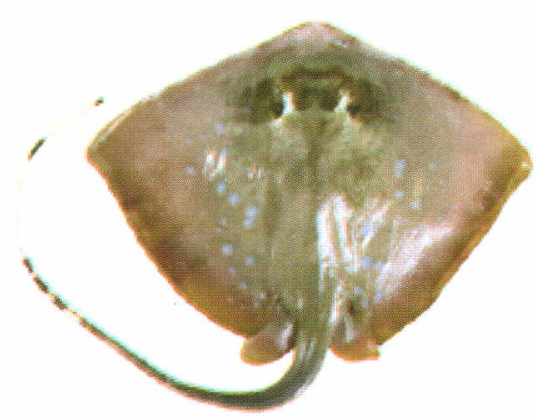

c. Băbi form.
Figure 3.

Another assumption is related to the differences in their habitats, life histories and fishing pressure. This assumption could be a better explanation for the differences in size at first maturity among Neotrygon kuhlii from west and east North Java, South Java, Malacca, East Sumatera, and West Kalimantan regions (Java form) rather than comparing them to Neotrygon kuhlii from South Natuna and East Kalimantan. Suitable habitat may affect to the species growth and productivity. Fishes will grow up and attain at larger size in a good habitat where foods are available rather than those living in a pressured environment and lack of food in their natural habitat. The flexibility in the life history of many species may lead to adaptation to inhabit in various habitats and environments, and the differences in size at maturity among species from different regions are a manifestation of the plasticity of the species reproduction (Lucifora et al., 1999). Therefore, quantity and size of species can vary between stocks or populations and also between areas (Lucifora et al., 1999; Andrade \& Campos, 2002). Fish also can attain its maturity in earlier stage as an adaptation from fishing pressure. According to Stearns in Lucifora et al. (1999), size at maturity responds very quickly both
Neotrygon kuhlii.

to natural selection and to additional selective pressures such as those caused by fisheries. Motta et al. (2005) suggested that the mean length at sexual maturity of a population in a high fishing pressure area decreases in response to the removal of large individuals in that area. For instance, the thorny skate Amblyraja radiata reached sexual maturity at different sizes in two areas in the north West Atlantic and it was suggested that local environmental conditions, life history and their flexibility to fishing were important factors in determining the differences (Templeman, 1987). The thornback ray (Raja clavata) from the North Sea were also mature at earlier age due to the heavy fishing pressure (Walker in Stevens et al., 2000).

The Java Sea and its adjacent area are known to be overexploited due to the high intense of fishing activities in the area (Bonfil, 2002; White et al., 2006b). As the most common ray species being caught in many demersal fisheries, Neotrygon kuhlii is a good indicator for this condition. The sizes at first maturity of Neotrygon kuhlii from the Java Sea and its adjacent area tend to be lower than those from south Java (Table 2). This means that there is plasticity in the size at maturity of Neotrygon kuhlii in the Java Sea and its 
adjacent area as an adaptation to the fishing pressure in the area. The lowest size at first maturity of the species from East Sumatera (including Bangka and Lampung), can indicate the level of fishing pressure in this area. Trawlers from Jakarta (Muara Angke) targeting for shrimps often operate in the area together with local fishers from Bangka and Lampung (pers. obs.). Other factors such as environmental quality degradations (water pollution, sedimentation, and transportation) and habitat destruction (sand mining) could also influence the life history of Neotrygon kuhlii in the area.

\section{CONCLUSIONS}

There were two possibilities in the difference of size at maturity of Neotrygon kuhlii from some fishing regions in Indonesia, i.e:

1. The possibility that Neotrygon kuhlii in Indonesia may consist of more than one species or populations, however, this statement need to be clarified by further studies on morphology and genetics.

2. The possibility of the difference of fishing pressure, environmental degradations and habitat destruction in the Java Sea and adjacent area comparing to other areas such as South Java, East Kalimantan, and South Natuna, may influence the population of Neotrygon kuhlii to grow and reproduce.

\section{ACKNOWLEDGMENT}

We thank to Norm Hall of Centre for Fish and Fisheries Reseach. Murdoch University Australia for Using FitLogistic Analysis and our thanks also go to William White of CSIRO Australia for his assistance in the data analysis. This Study was funded by DIPAIndonesian Institute of Sciences in 2003 and Census of Marine Life Program. Indonesian Institute of Sciences from 2004 to 2006.

\section{REFERENCES}

Adrim, M. \& Fahmi. 2007. Characteristics of chondrichthyan diversity in western Indonesia. Jurnal IImu-ilmu Perairan dan Perikanan Indonesia. 14 (2): p. 137-150.

Andrade, H. A. \& Campos, R. O. 2002. Allometry coefficient variations of the length weight relationship of skipjack tuna (Katsuwonus pelamis) caught in the southwest South Atlantic. Fisheries Research. 55: p. 307-312.
Bonfil, R. 1994. Overview of world elasmobranch fisheries. FAO. Rome $119 \mathrm{pp}$.

Bonfil, R. 2002. Trend and patterns in world and Asian elasmobranch fisheries. In S. L. Fowler, T. M. Reed, \& F. A. Dipper (eds.). Elasmobranch Biodiversity, Conservation, and Management. Proceeding of the International Seminar and Workshop in Sabah, July 1997. Gland, Switzerland, and Cambridge, UK. IUCN SSC Shark Specialist Group. 15-24 pp.

Camhi, M. S., Fowler, S., Musick, J., Brautigam, A., \& Fordham, S. 1998. Sharks and their relativesecology and conservation. IUCN SSC Shark Specialist Group. Gland. Switzerland and Cambridge. UK: p. iv +39 .

Dharmadi \& Fahmi. 2006. Tingkat kematangan kelamin dan frekuensi panjang pari gitar (Rhinobatus sp.1 dan Rhinobatus sp.2). Bawal. 1 (1): p. 31-35.

Frisk, M. G., Miller, T. J., \& Fogarty, M. J. 2001. Estimation and analysis of biological parameters in elasmobranch fishes: A comparative life history study. Canadian Journal Fishery Aquatic Sci. 58: p. 969-981.

Hazin, F., A. Fischer, \& M. Broadhurst. 2001. Aspect of reproductive biology of the scalloped hammerhead shark, Sphyrna lewini, off Northeastern Brazil. Environmental Biology of Fishes, 61: p. 151-159.

Howell, D. C. 1997. Statistical methods for psychology (4th ed.). Duxbury Press. Belmont. CA. pp.

Jennings, S., Reynold, J. D., \& Mills, S. C. 1998. Life history correlates of response to fisheries exploitation. Proc. R. Soc. Lond. B. 265: 333-339.

Last, P. R. \& Compagno, L. J. V. 1999. Dasyatidae: Stingrays. In K. E. Carpenter \& V. H. Niem (eds.). FAO Species Identification Guide for Fishery Purposes. The Living Marine Resources of the Western Central Pacific. Batoid Fishes, Chimaeras, and Bony Fishes Part 1 (Elopidae to Linophrynidae). Rome. FAO. p. 1.479-1.505.

Last, P. R. \& White, W. T. 2008. Resurrection of the genus Neotrygon Castelnau (Myliobatoidei: Dasyatidae) with the description of Neotrygon picta sp. nov., a new species from northern Australia. In P. R. Last, W. T. White, \& J. J. Pogonoski (eds.). 
Descriptions of new Australian chondrichthyans. CSIRO Marine and atmospheric Reseach Paper. 022: p. 315-326.

Liu, K. M., Chen, C. T., Liao, T. H., \& Joung, S. J. 1999. Age, growth, and reproduction of the pelagic thresher shark, Alopias pelagicus in the Northwestern Pacific. Copeia. 1: 68-74.

Lucifora, L. O., Valero, J. L., \& Garcia, V. B. 1999. Length at maturity of the greeneye spurdog shark, Squalus mitsukurii (Elasmobranchii: Squalidae), from the SW Atlantic, with comparisons with other regions. Marine Freshwater Research. 50: p. 629632.

Mardlijah, S. \& Pralampita, W. A. 2004. Beberapa parameter biologi ikan pari Dasyatis kuhlii (Famili Dasyatidae) di perairan Laut Jawa. Jurnal Penelitian Perikanan Indonesia Edisi Sumber Daya dan Penangkapan. 10 (6): p. 55-59.

Motta, F. S., Gadig, O. B. F., Namora, R. C., \& Braga, F. M. S. 2005. Size and sex compositions, length weight relationship, and occurrence of the Brazilian sharpnose shark, Rhizoprionodon lalandii, caught by artisanal fishery from southeastern Brazil. Fisheries Research. 74: p. 116-126.

Oshitani, S., Nakano, H., \& Tanaka, S. 2003. Age and growth of the silky shark Carcharhinus falciformis from the Pacific Ocean. Fisheries Science. 69: p. 456-464.

Seki, T., Taniuchi, T., Nakano, H., \& Shimizu, M. 1998. Age, growth, and reproduction of the oceanic whitetip shark from the Pacific Ocean. Fisheries Science. 6 4(1): p. 14-20.

Simpfendorfer, C. A. 1992. Reproductive strategy of the Australian sharpnose shark, Rhizoprionodon taylori (Elasmobranchii: Carcharhinidae), from Cleveland Bay, Northern Queensland. Australia Journal Marine Freshwater Research. 43: p. 6775.

Stevens, J. D., Bonfil, R., Dulvy, N. K., \& Walker, P. A. 2000. The effect of fishing on sharks, rays, and chimaeras (Chondrichthyans), and the implications for marine ecosystem. ICES Journal of Marine Science. 57: p. 476-494.

Stevens, J. D. \& MCLoughlin, K. J. 1991. Distribution, size, and sex composition, reproductive biology and diet of sharks from Northern Australia. Australia Journal Marine Freshwater Research. 42: p. 151199.

Templeman, W. 1987. Differences in sexual maturity and related characteristicsbetween populations of thorny skate (Raja radiata) from the Northwest Atlantic. Journal Northwest Atlantic Fisheries Science. 7: p. 155-167.

Wetherbee, B. M., Crow, G. L., \& Lowe, C. G. 1997. Distribution, reproduction, and diet of the gray reef shark Carcharhinus amblyrhynchos in Hawaii. Marine Ecology Prog. Ser. 151: p. 181-189.

White, W. T. \& Dharmadi. 2007. Species and size compositions and reproductive biology of rays (Chondrichthyes, Batoidea) caught in target and non target fisheries in eastern Indonesia. Journal of Fish Biology. 70: p. 1.809-1.837.

White, W. T., Giles, J., Dharmadi, \& Potter, I. C. 2006a. Data on the bycatch fishery and reproductive biology of moiulid rays (Myliobatiformes) in Indonesia. Fisheries Research. 82: p. 65-73.

White, W. T., Hall, N. G., \& Potter, I. C. 2002. Size and age compositions and reproductive biology of the nervous shark Carcharhinus cautus in a large subtropical embayment, including an analysis of growth during pre and postnatal life. Marine Biology. 141: p. 1.153-1.164.

White, W. T., Last, P. R., Stevens, J. D., Yearsley, G. K., Fahmi, \& Dharmadi. 2006. Economically Important Sharks and Rays of Indonesia. ACIAR. Canberra. 329 pp.

Zar, J. H. 1999. Biostatistical Analysis (4th ed.). Prentice Hall International Inc. 663 p + 212A pp. 
